\title{
PERSONALIA W DRUGIM LIŚCIE DO TYMOTEUSZA 4,9-15
}

W 2Tm 1,4 apostoł Paweł po raz pierwszy w tym liście wyraził swoje pragnienie, aby ponownie spotkać się z Tymoteuszem. ${ }^{1}$ Powtórzył je w 2Tm 4, 9, ale uczynił to bardziej bezpośrednio, emfatycznie,

1 W niniejszym opracowaniu, ze względu na zakres tematyczny, nie podejmujemy dyskusji nad kwestią autorstwa Pierwszego i Drugiego Listu do Tymoteusza (całego Corpus Pastorale). Zob. bogatą literaturę tego zagadnienia np. T. M a $\mathrm{n}$ a b o, Persönliche Korrespondenz des Paulus. Zur Strategie der Pastoralbriefe als Pseudepigrapha, New Testament Studies 56/2010, s. 253-272; W. R a k o c y, Pawet Apostot. Chronologia życia i pism, Częstochowa 2008², s. 345-371; G. H ä f n e r, Das Corpus Pastorale als literarisches Konstrukt, Theologische Quartalschrift 187/2007, s. 258-259; A. M e r z, Amore Pauli: Das Corpus Pastorale und das Ringen um die Interpretationshoheit bezüglich des paulinischen Erbes, tamże, s. 274-294; S.J. S t a s i a k, Problemy krytyczno-literackie Listów Pasterskich, Perspectiva 3(2004) nr 2, s. 52-66; M. P r i o r, Paul the Letter-Writer and the Second Letter to Timothy, Journal for the Study of the New Testament. Supplement Series 23, Sheffield 1989; L.R. D o n e 1 s o n, Pseudepigraphy and Ethical Argument in the Pastoral Epistles, Hermeneutische Untersuchungen zur Theologie 22, Tübingen 1986; R. F a b r is, Il paolinismo delle Lettere Pastorali, Rivista Biblica 34/1986, s. 451-470; A. M o d a, Le Lettere Pastorali e la biografia di Paolo. Saggio bibliografico, Bibbia e Oriente 145/1985, s. 149-161; J. v a n B r u g g e n, Die geschichtliche Einordnung der Pastoralbriefe, Wuppertal 1981; P. T r u m m e r, Corpus Paulinum-Corpus Pastorale. Zur Ortung der Paulustradition in den Pastoralbriefen, w: K. K e r t e 1 g e (red.), Paulus in den neutestamentlichen Spätschriften. Zur Paulusrezeption im Neuen Testament, Quaestiones Disputatae 89, Freiburg im Breisgau-Basel-Wien 1981, s. 122-145; t e n ż e, Die Paulustradition der Pastoralbriefe, Beiträge zur biblischen Exegese und Theologie 8, Frankfurt am Main-Bern-Las Vegas 1978; A. L e m a i r e, Épitres Pastorales: Rédaction et Théologie, Bulletin de Théologie Biblique 2/1972, s. 24-41; J. S t ę p i e ń, Problem autorstwa Listów Pasterskich, Studia Theologica Varsaviensia 6(1968) nr 2, s. 157-199. Zob. także przyp. 47. 
wręcz praktycznie. $^{2}$ Nawet sprecyzował, by Tymoteusz zdążył przybyć do niego jeszcze przed zimą (zob. 2Tm 4,21). Wyrażając to pragnienie, Paweł pokrótce opisał swoją sytuację jako więźnia oraz przekazał informacje o ośmiu osobach, które tworzyły grono jego współpracowników lub były z nim w jakiejś relacji (w. 9-15). W niniejszym artykule chcemy przyjrzeć się tym postaciom oraz w ramach możliwości - dokonać analizy ich zadań lub decyzji, które zostały przez nie podjęte. Kluczowym naszym obszarem badawczym będzie passus 2 Tm 4,9-15, w którym osoby te zostały wymienione $\mathrm{z}$ imienia.

\section{Propozycja przekładu 2Tm 4,9-15}

„9 Dołóż starań, aby szybko przybyć do mnie. ${ }^{10}$ Demas bowiem mnie opuścił, gdyż umiłował świat doczesny i udał się do Tesaloniki, Krescens do Galacji, Tytus do Dalmacji. ${ }^{11}$ Tylko Łukasz jest ze mną. Zabierz Marka i przyprowadź ze sobą, gdyż jest mi bardzo pomocny w posłudze. ${ }^{12}$ Tychika wysłałem natomiast do Efezu. ${ }^{13}$ Zmierzając do mnie, weź po drodze płaszcz, który pozostawiłem u Karpa w Troadzie, oraz księgi, a zwłaszcza pergaminy. ${ }^{14}$ Brązownik Aleksander wyrządził mi wiele zła - stosownie do uczynków jego zwróci mu Pan. ${ }^{15}$ Ty również uważaj na niego, gdyż stanowczo wystąpił przeciw naszym słowom".

Miejsce tekstu w strukturze Drugiego Listu do Tymoteusza

Passus 4,9-15 otwiera zakończenie Drugiego Listu do Tymoteusza. ${ }^{3}$ Stanowi on pierwszą jego część, informującą Tymoteusza o sprawach

2 Por. A.E. Martín e z, Timoteo y Tito, Conozca su Biblia, Minneapolis 2008, s. 101.

3 Podział listu: Wstęp $(1,15)$; część pierwsza: „kwestia wierności” $(1,6-2,13)$; część druga: „kwestia prawdy i błędu” (2Tm 2,14 - 4,8); zakończenie (4,9-22). Zob. przykładowe podziały listu: R.A. W i l d, Listy Pasterskie, w: R.E. B r o w n, J.A. Fitzmyer, R.E. Murphy (red. nauk. wyd.), W. Chrostowski (red. nauk. wyd. pol.), Katolicki komentarz biblijny, Prymasowska Seria Biblijna 17 
personalnych. ${ }^{4}$ Podobną notę, ale odnoszącą się do innych osób, apostoł sporządził już w 2 Tm 1,15-18. ${ }^{5}$

Sekcja ta jest wyraźnie oddzielona od poprzedniej (w. 6-8) przez

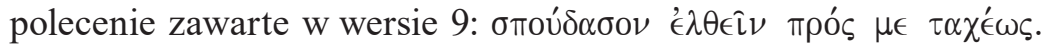
Wezwanie Tymoteusza do Rzymu wyznacza temat przewodni całej perykopie (w. 9-18). Bezpośrednio po niej znajdują się już tylko końcowe pozdrowienia, dodatkowe informacje (w. 19-21) oraz podwójne błogosławieństwo (w. 22).

W literaturze przedmiotu fragment ten (w. 9-18) jest często porównywany z Ps 22. Eksponuje się w niej aspekt opuszczenia (psalmisty przez Boga - zob. Ps 22,2-3.12 i Pawła przez ludzi - zob. 2Tm 4,10.16) oraz wybawienia z paszczy lwa (Ps 22,22 - 2Tm 4,17). Być może uwięziony apostoł, wyczuwając zbliżającą się śmierć, posłużył się językiem tego psalmu. ${ }^{6}$

(PSB), Warszawa 2001, s. 1448; J.D. M i 11 e r, The Pastoral Letters as Composite Documents, Monograph series. Society for New Testament Studies 93, Cambridge 1997, s. 96-123.

4 Część druga: „sytuacja prawna Pawła” (w. 16-18); część trzecia: „pozdrowienia i polecenia” (w. 19-21); część czwarta: „końcowe, podwójne błogosławieństwo dla Tymoteusza i czytelników”.

5 Tematyczną analogię obydwu informacji eksponują w swoim komentarzu J.D. Q u i n n, W.C. W a c k e r, The First and Second Letters to Timothy. A New Translation with Notes and Commentary, The Eerdmans Critical Commentary, Grand Rapids-Cambridge 2000, s. 565; zob. także: J. W i 1 k, Polaryzacja postaw wspótwyznawców wobec uwięzionego Pawła na podstawie 2 Tm 1,15-18, w: M. S z m a j d z i ń s k i (red.), Gloriam praecedit humilitas (Prz 15,33). Księga Pamiątkowa dla Księdza Profesora Antoniego Troniny w 70. rocznice urodzin, Częstochowa 2015, s. 813-828.

6 Zob. szczegółową analizę paraleli między Ps 22 a 2Tm 4,9-18: W. L o c k, A Critical and Exegetical Commentary on the Pastoral Epistles (I \& II Timothy and Titus), The International Critical Commentary on the Holy Scriptures of the Old and New Testaments (ICC), Edinburgh $1989^{2}$, s. 116; A.T. H a n s o n, The Pastoral Epistles, The New Century Bible Commentary, Grand Rapids-London 1982, s. 162; C. S p i c q, Saint Paul. Les Épîtres Pastorales, Études Bibliques, Paris $1969^{4}$, t. II, s. 809-810; W.D. M o u n c e, Pastoral Epistles, Word Biblical Commentary 46, Nashville 2000, s. 587. 
Struktura 2Tm 4,9-15(18)

Sekcja 2Tm 4,9-18 zawiera wszystkie cechy starożytnego listu osobistego. Autor usilnie prosi odbiorcę, by jak najszybciej przybył do miejsca jego pobytu (w. 9); wyjaśnia przyczynę tego polecenia (w. 10-11a), wskazuje kogo i co ma ze sobą zabrać (w. 11b-13) oraz na kogo uważać podczas podróży (w. 14-15). Całość kończy informacją, jak aktualnie toczą się jego sprawy (w. 16-18). ${ }^{7}$ Gdyby list ten zawierał tylko te słowa, traktowałby o sprawach zupełnie zwyczajnych, nie budzących zdziwienia. Byłby jednym spośród tysięcy listów tego typu, które przemierzały codziennie świat hellenistyczny. ${ }^{8}$ Tymczasem został on poprzedzony dłuższym pismem (wcześniejsze rozdziały 2Tm), wzywającym Tymoteusza do wierności nauce Ewangelii i jej obrony wobec błędnowierców. Przez słowa zawarte w 2Tm 4,9-18 apostoł zwrócił się po raz ostatni do „umiłowanego dziecka w wierze” (1Tm 1,2; $2 \mathrm{Tm} 1,2)$, eksponując ludzi i sprawy, które były im dobrze znane.

Strukturę 2Tm 4,9-15 można określić na podstawie poruszanych przez Pawła tematów. W analizowanym tekście są to dwa zagadnienia: instrukcje dla Tymoteusza (A) oraz informacje o osobach związanych z Pawłem (B). Graficznie struktura ta przedstawia się w następującym układzie: ${ }^{9}$
$1 \operatorname{Tm} 4$
A1 w. 9
Instrukcja dla Tymoteusza
B1 w. 10-11a
A2 w. 11b

\section{Temat}
Informacja o osobach związanych z Pawłem
Instrukcja dla Tymoteusza

7 Por. G.D. Fe e, Comentario de las Epístolas a $1^{a}$ y $2^{a}$ de Timoteo y Tito, Estudios bíblicos 23, Viladecavalls, Barcelona 2008, s. 330 Strukturę listu antycznego zob. H.J. K 1 a u c k, Die antike Briefliteratur und das Neue Testament, Uni-Taschenbücher 2022, Padeborn 1998, s. 54; J. S c h n a y d e r (oprac.), List antyczny. Antologia, Arcydzieła Kultury Antycznej, Wrocław $2006^{2}$.

8 Por. G.D. F e e, Comentario de las Epistolas a $1^{a}$ y $2^{a}$ de Timoteo y Tito, s. 330 .

9 Zob. M. G o u r g u e s, Les deux lettres à Timothée. La lettre à Tite, Commentaire biblique: Nouveau Testament 14, Paris 2009, s. 335. 


\section{$1 \operatorname{Tm} 4$}

B2 w. 12

A3 w. 13

B3 w. 14

A4 w. 15

\section{Temat}

Informacja o osobach związanych z Pawłem Instrukcja dla Tymoteusza Informacja o osobach związanych z Pawłem Instrukcja dla Tymoteusza

Sekcja została skonstruowana na bazie symetrii równoległej (paralelnej). Poszczególne wskazówki, które otrzymał Tymoteusz (A), znajdują swoje odniesienia w tym, co działo się w życiu Apostoła Narodów (B). Kluczowa para $\mathrm{A}^{1}-\mathrm{B}^{1}$ podejmuje kwestię osamotnienia uwięzionego w Rzymie Pawła. Ogniwo $\mathrm{A}^{2}-\mathrm{B}^{2}$ odnosi się do dwóch bliskich jego towarzyszy podróży misyjnych, a para $\mathrm{A}^{3}-\mathrm{B}^{3}$ do konkretnych spraw związanych z życiem apostoła. Człon $\mathrm{A}^{4}$ wynika bezpośrednio z $\mathrm{B}^{3}$.

Przez zastosowanie w instrukcjach (A) czasowników w trybie

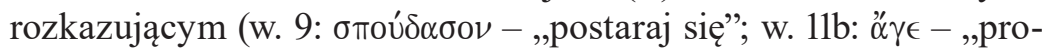
wadź”; w. 13: ф́́ $€ \epsilon$ - „przynieś”; w. 15: fula,ssou - „strzeż się”), przybrały one formę poleceń, które równocześnie wyrażają osobiste prośby apostoła. ${ }^{10}$ Pod względem tematycznym i syntaktycznym cała perykopa charakteryzuje się logiczną spójnością.

\section{Poszczególne postacie i ich charakterystyka w 2Tm 4,9-15}

Apostoł Paweł, wzywając Tymoteusza, aby jak najszybciej $\left(\tau \alpha \chi \chi^{\prime} \omega \varsigma\right)^{11}$ przybył do Rzymu (w. 9), odniósł się pokrótce do innych osób, prawdopodobnie tworzących jego najbliższe środowisko. Imiennie wyliczył ich osiem: Demas, Krescens, Tytus, Łukasz, Marek, Tychik, Karp, Aleksander. Zamieszczenie ich w liście skierowanym

10 Por. R. P o p ow s k i, Imperatiwus na tle indikatiwu w listach Pawła z Tarsu. Studium językowo-egzegetyczne, Lublin 1988, s. 304-305.

11 Paweł miał już pewne doświadczenie w rzymskim systemie sądowniczym (zob. w. 16-17) i mógł przypuszczać, że nawet jeśli nie zostanie uwolniony, to jednak wykonanie ewentualnego wyroku skazującego zajmie Rzymianom trochę czasu, dlatego to ponaglenie Tymoteusza (zob. także w. 21). 
do Tymoteusza, może oznaczać, że wszyscy oni byli znani adresatowi. W całym Corpus Paulinum ${ }^{12}$ zostali oni wymienieni w:

$\mathrm{Rz}$

1 Kor

2 Kor

2,13;

7,6.13.14;

8,6.16.23;

12,18

$\mathrm{Ga}$

2,1.3

Ef
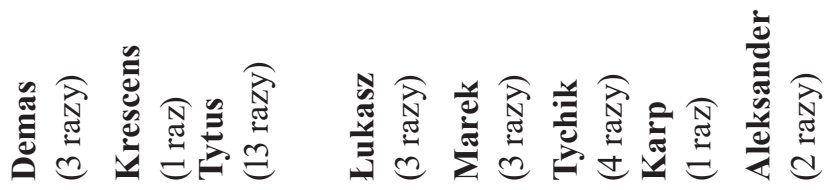

Flp

Kol

1 Tes

2 Tes

$1 \mathrm{Tm}$

2 Tm

$\mathrm{Tt}$

Flm

Spośród przedstawionych w 2Tm 4,9-15 osób w Corpus Paulinum najczęściej jest wymieniany Tytus (13 razy), głównie w kontekście jego misji w Koryncie. Dwie osoby zostały wspomniane tylko w analizowanej perykopie (Krescens i Karp). W największej liczbie listów (po cztery) zostali wyszczególnieni Tytus i Tychik. Dwa listy (Kol i Flm) zawierają najwięcej imion osób zaprezentowanych w interesującym nas fragmencie.

12 W niniejszym studium, posługując się konstrukcją Corpus Paulinum, określa się wszystkie listy proto-Pawłowe i deutero-Pawłowe. 


\section{Demas}

Imię Demas $(\Delta \eta \mu \hat{\alpha} \varsigma)$ może być skrótem od Demetrios lub Demarchus: „zarząd ludu”, ,naczelnik ludu”, „,człowiek z ludu” lub „pochodzący od Demeter" (greckiej bogini płodów rolnych). ${ }^{13}$ Demas, należał do współpracowników Pawła, o czym sam apostoł pisze w Liście do Filemona (w. 24). Wspomniał również o nim, pozdrawiając Kolosan (Kol 4,14).

Prawdopodobnie pochodził on z Tesalonik, do których powrócił, opuszczając uwięzionego Pawła. Nic nie wiemy, jak znalazł się w gronie jego najbliższych współpracowników (może spotkali się w Tesalonikach, w trakcie podróży misyjnych Apostoła Narodów?). Należy przypuszczać, że Demas był przy Pawle podczas pierwszego uwięzienia w Rzymie (lata 59-61), kiedy to powstały listy do Filemona oraz do Kolosan, a w których jest on imiennie wspominany. ${ }^{14}$

Paweł informował Tymoteusza, że „Demas go opuścił

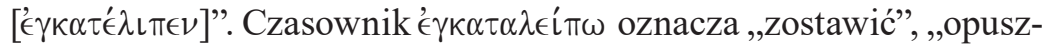
czać” „porzucić”. ${ }^{15}$ W Nowym Testamencie, gdzie występuje on dziesięciokrotnie, określa opuszczenie kogoś lub cośn ${ }^{16}$. Dlatego opuszczenia (pozostawienia) Pawła przez Demasa nie powinno się interpretować jako apostazję, ale raczej jako zwykłą „dezercję”. Tym bardziej że apostoł, pisząc w tym samym liście o odwróceniu się od niego tych, którzy są w Azji, a wśród nich Figelosa i Hermogenesa (zob.

13 Zob. Demas, w: P.C. B o s a k, Postacie Biblii. Słownik-konkordancja, Pelplin 2001, t. II, s. 592; $\downarrow \eta \mu \hat{\alpha} \varsigma$, w: W. B a u e r, Griechisch-deutsches Wörterbuch zu den Schriften des Neuen Testaments und der frühchristlichen Literatur, Berlin-New York $1988^{6}$, kol. 357.

14 Por. K. R o m a n i u k, Uczniowie $i$ współpracownicy świętego Pawła, Kraków 2008, s. 63-64. Zob. także W. R a k o c y, Pawet Apostoł, gdzie na s. 299-305 autor omawia zagadnienie pierwszego uwięzienia Pawła w Rzymie, a na s. 306-328 problem autorstwa i miejsca powstania Flm i Kol.

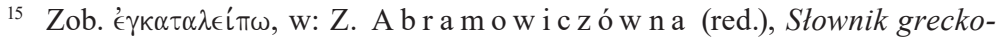
-polski (SGP), Warszawa 1960, t. II, s. 12.

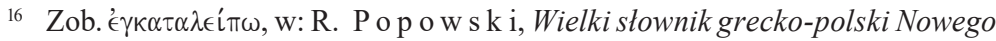
Testamentu. Wydanie z petna lokalizacja greckich haset, kluczem polsko-greckim oraz indeksem form czasownikowych (WSGPNT), PSB 3, Warszawa 1995², s. 153. 


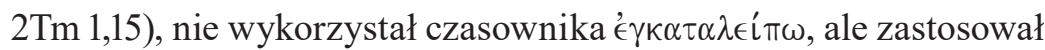

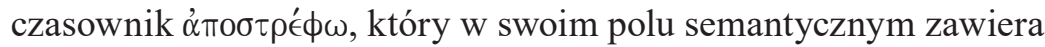
znaczenia: „odwracać”, „porzucać”, ale i „zawrócić w przeciwną stronę". ${ }^{17}$ W Nowym Testamencie występuje on dziewięciokrotne, z czego trzykrotnie w Corpus Pastorale, zawsze w znaczeniu ,odwracać się od kogoś lub czegoś” (zob. 2Tm 1,15; 4,4; Tt 1,14). W 2Tm 4, 4 i Tt 1,14 określa odwrócenie się od prawdy, a w 2Tm 1,15 od osoby ${ }^{18}$ Kontekst zastosowania tego czasownika w Listach Pasterskich, może wskazywać nie tylko na fizyczne opuszczenie Pawła przez osoby wymienione w $2 \mathrm{Tm} 1,15$, ale również na apostazję - porzucenie Ewangelii, którą głosił apostoł, czyli samego Chrystusa. ${ }^{19}$

Demas z powodu zaostrzenia rygorów uwięzienia Pawła ${ }^{20}$ lub lękając się, aby nie podzielić jego losu, ${ }^{21}$ zwyczajnie go opuścił, powracając do rodzinnych (?) Tesalonik. Apostoł, opisując decyzję

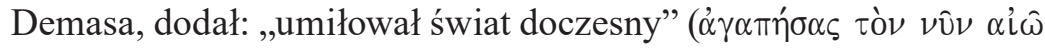
$\nu \alpha$ - dosł. „umiłowawszy ten teraz wiek”). Jan Chryzostom, prawdopodobnie podzielając opinię o niebezpieczeństwie grożącym tym, którzy w Rzymie kontaktowali się z uwięzionymi chrześcijanami, tak skomentował decyzję Demesa, wkładając w usta Pawła następujące

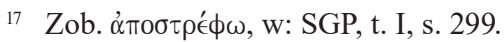

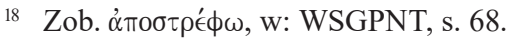

19 Por. J. W il k, Polaryzacja postaw wspótwyznawców wobec uwięzionego Pawta na podstawie 2 Tm 1,15-18, s. 819.

20 Prawdopodobnie drugie uwięzienie Pawła w Rzymie (między wiosną/latem 63 [64], a wiosną /latem 64 [65]) było bardziej surowe niż to opisane w Dz 28,23.30-31. Pogląd ten wspiera fakt, że kiedy Onezyfor przybył do Rzymu, nie mógł od razu odnaleźć uwięzionego Apostoła Narodów, ale musiał go przez dłuższy czas wytrwale poszukiwać (zob. 2Tm 1,16-17), co sugeruje, że Paweł był w odosobnionym i dobrze strzeżonym miejscu. W kwestii drugiego rzymskiego uwięzienia Pawła zob. W. R a k o c y, Pawet Apostot, s. 371-377.

${ }_{21}$ Istniało realne zagrożenie, że osoby spotykające się z uwięzionym skazańcem (chrześcijaninem) mogły zostać posądzone o czynne popieranie chrześcijaństwa. Zarzut ten spotęgował się podczas prześladowań chrześcijan za Nerona; zob. Te o d o r e t z Cyru, Komentarz do listów Pawłowych do Tesaloniczan, Tymoteusza, Tytusa, Filemona i Hebrajczyków, tłum. S. K a 1 i n k o w s k i, Źródła Myśli Teologicznej 20, Kraków 2001, s. 168 
słowa: „Umiłowawszy spokój, wolność od niebezpieczeństw i bezpieczność, wolał w domu używać dostatku, niż ze mną biedować i znosić razem ze mną obecne niebezpieczeństwa". Złotousty pisze ponadto: „Tego jednak oskarżył, nie jakoby chciał oskarżać, lecz by nas utwierdzić, abyśmy nie miękli w niebezpieczeństwach i trudach". ${ }^{22}$ Co Demas czynił później? - tego nie wiemy. Nie brak jednak opinii, że mógł nadal aktywnie działać jako chrześcijanin, angażując się nawet $\mathrm{w}$ prace misyjne. ${ }^{23}$

\section{Krescens}

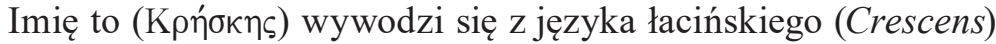
i oznacza „rosnący”, „wzrastający”. ${ }^{24} \mathrm{Na}$ kartach Biblii występuje tylko raz (2Tm 4,10). Prawdopodobnie Krescens był najpierw uczniem, a później współpracownikiem Apostoła Narodów. Przez pewien czas był z nim podczas drugiego uwięzienia w Rzymie, by potem wyruszyć do Galacji w Azji Mniejszej. Nie znamy żadnych szczegółów związanych z tą decyzją: Czy jego odejście oznaczało

22 Jan Chry z o s to m, Homilia Xna II List do Tymoteusza, X, 1, w: t e n że, Homilie na Listy Pasterskie św. Pawła i na List do Filemona (I-II Tym. - Tyt. - Filem.), tłum. i wstęp T. S i n k o, Złoty Wiek Myśli Chrześcijańskiej X.8, Kraków 1949, s. 292-293.

23 Por. I.H. M a r s h a 11, The Pastoral Epistles, ICC, Edinburgh 1999, s. 815-816; C. S p i c q, Saint Paul, t. II, s. 810-811. Tym samym, jak podkreśla K. R o m a n i u k, należy odrzucić stanowisko, jakoby dokonując apostazji, Demas został kapłanem pogańskim w rodzinnej Tesalonice lub też po przybyciu z Rzymu do Tesalonik, stał się wyznawcą herezjarchy Cerynta; zob. te n ż e, Uczniowie $i$ wspótpracownicy świętego Pawła, s. 64.

24 Zob. Krescens, w: P.C. B o s a k, Postacie Biblii. Słownik-konkordancja, t. VI, s. 621-622. Zob. transkrypcje tego imienia we współczesnych przekładach

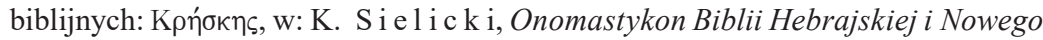
Testamentu. Systematyzacja zapisu biblijnych nazw własnych, PSB 33, Warszawa 2009, s. 286. Imię znane w literaturze chrześcijańskiej zob. np. Ś w. P o li k a r p ze Smyrny, List do Kościoła w Filippi, XIV, 1, w: M. S t a r o w i e y s k i (oprac.), Pierwsi świadkowie. Pisma Ojców Apostolskich, tłum. A. Św i d e rków n a, Biblioteka Ojców Kościoła 10, Kraków 2010², s. 161 
całkowitą rezygnację z pracy misyjnej, czy wyruszył do Galacji jako misjonarz z własnej gorliwości, czy też na wyraźne polecenie Pawła? Zestawienie Krescensa z Tytusem - sumiennym i wytrwałym współpracownikiem Pawła - sugeruje, że bardziej była to wyprawa misyjna niż opuszczenie uwięzionego apostoła. ${ }^{25}$ Według tradycji, Krescens miał umrzeć jako biskup Chalcedonu (Galacja-Bitynia), za panowania cesarza Trajana (panował w latach 98-117). ${ }^{26}$

Inna hipoteza opiera się na krytyce tekstu. Wskazuje ona, że niektóre manuskrypty zamiast nazwy $\Gamma \alpha \lambda \alpha \tau i \alpha \nu$ (,Galacja” w Azji Mniejszej) posiadają $\Gamma \alpha \lambda \lambda \iota \alpha \nu$ („Galię” - krainę w zachodniej Europie). ${ }^{27}$ Dodać ponadto należy, że niektórzy antyczni pisarze do określenia krainy położonej w zachodniej Europie używali także nazwy $\Gamma \alpha \lambda \alpha \tau i \alpha$ („Galatia”), a Galów nazywali Galatami. ${ }^{28}$ Trudno jednakże orzec, która z tych hipotez jest najbliższa prawdzie.

\section{Tytus}

Imię Tytus (Títos) należy do najstarszych imion łacińskich (Titus), tzw. praenomen (imię właściwe). W dosłownym przekładzie oznacza

25 Por. Ja n Chry zo s to m, Homilia Xna II List do Tymoteusza, X, 1: „tych już nie oskarża".

26 Zob. M. S t a r o w i e y s k i (oprac.), Imiona Apostołów. O siedemdziesięciu Apostołach, 15, w: t e n ż e (red.), Apokryfy Nowego Testamentu, Kraków 2007, t. II: Apostołowie, cz. 2, s. 1197; Krescens, w: P.C. B o s a k, Postacie Biblii. Słownik-konkordancja, t. VI, s. 622; M. Ern s t, Krescens, tłum. T. S i e m i e n i e c, w: F. K o g le r, R. Eg ger-Wenze 1, W. Ern s t (red. nauk.), H. W it c z y k (red. nacz. wyd. pol.), Nowy Leksykon Biblijny, Kielce 2011, s. 366.

27 Zob. kytykę tekstu ad locum: E. Ne st le, B. A l a nd, K. A l a nd, J. K a ravid o p oulos, C.M. Martin i, B.M. Metzger (oprac.), Novum Testamentum Graece, Stuttgart 200427. E u z e b i u s z z Cezarei pisze: „Krescens został posłany do Galii"; t e n ż e, Historia kościelna. Tekst grecki i polski, tłum. A. C a b a, Źródła Myśli Teologicznej 70, Kraków 2013², III, 4, 8.

28 Por. J. S tę p i eń, Listy do Tesaloniczan i Pasterskie. Wstęp, przekt. z oryginału, komentarz, Pismo Święte Nowego Testamentu IX (PŚNT), Poznań-Warszawa 1979, s. 447. 
„dzikiego gołębia”. Popularne w czasach Imperium Rzymskiego. ${ }^{29}$ W Starym Testamencie (LXX) występuje tylko raz, określając jednego z rzymskich legatów (zob. 2Mch 11,34), a w Nowym Testamencie zapisano je wyłącznie w Corpus Paulinum (13 razy), zawsze w odniesieniu do współpracownika Pawła i jednocześnie adresata jednego z listów. ${ }^{30}$

Według przekazów apokryficznych, ród Tytusa miał wywodzić się „od Minosa, króla Krety”. ${ }^{31}$ Wydaje się jednak bardziej słuszne doszukiwanie się korzeni Tytusa, Greka z pochodzenia (zob. Ga 2,3), w Antiochii Syryjskiej. ${ }^{32}$ Niewykluczone jest pokrewieństwo między nim a Łukaszem ewangelistą, który według wczesnych świadectw chrześcijańskich wywodził się również z tego miasta. ${ }^{33}$ Zarówno Łukasz w Dziejach Apostolskich, jak i sam Apostoł Narodów milczą o początkach więzi Pawła i Tytusa. Paweł nazwał go „prawowitym dzieckiem we wspólnej wierze" (Tt 1,4). Z czasem pozycja Tytusa w zespole misyjnym apostoła stała się kluczowa, na co wskazuje: jego udział na tzw. Soborze Jerozolimskim (zob. Ga 2,1), troska o Kościół

${ }^{29}$ Nosił je m.in. cesarz rzymski Titus Flavius V (sprawował ten urząd w latach 79-81 po Chr.).

30 Według niektórych rękopisów, imię to miał również nosić jeden z mieszkańców Korytu; zob. krytykę tekstu (Novum Testamentum Graece) do Dz 18,7 (Tıтíou

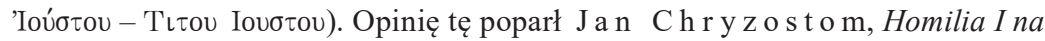
List do Tytusa, I, 1, w: t e n ż e, Homilie na Listy Pasterskie św. Pawła i na List do Filemona (I-II Tym. - Tyt. - Filem.), s. 305. W egzegezie pogląd ten nie znalazł szerszego poparcia.

${ }^{31}$ Legenda Kreteńska Świętego Tytusa (Dzieje Tytusa), 1, tłum. R. Z a w a d z k i, w: M. S t a r o w i e y s k i (oprac.), Apokryfy Nowego Testamentu, t. II, cz. 2, s. 1179.

32 Por. K. Ro m a n i u k, Uczniowie i wspótpracownicy świętego Pawła, s. 167.

33 Por. W. R a k o c y, Tytus krewnym Łukasza?, Roczniki Teologiczne. Pismo Święte, t. LI (2004), z. 1, s. 115-125. 
w Koryncie (zob. 2Kor 2,13; 7,6.13.14; 8,6.16.23; 12,18) ${ }^{34}$ oraz misja na Krecie (List do Tytusa). ${ }^{35}$

2Tm 4,10 zawiera jedynie wiadomość, że Tytus udał się Dalmacji (por. Rz 15, 19). ${ }^{36}$ Niestety, brak jest jakichkolwiek informacji skąd i w jakim celu wyruszył on do tej krainy. Prawdopodobnie najbliżsi prawdy historycznej są ci, którzy twierdzą, że Tytus, wezwany przez Pawła, opuścił na pewien czas Kretę 37 i towarzyszył Apostołowi Narodów w jego drugiej podróży do Rzymu i z tego miasta udał się z nieznaną nam co do przyczyny oraz celu misją do Dalmacji. Przypuszcza się, że zdążył z niej powrócić jeszcze za życia Pawła, pozostając z nim aż do jego męczeńskiej śmierci. ${ }^{38}$ Po tym wydarzeniu miał wrócić z Rzymu na Kretę, gdzie troszczył się o tamtejszy Kościół, aż do swojej naturalnej śmierci (przeżył 94 lata). ${ }^{39}$

34 Zob. także: J. W i 1 k, Podwójny powód radości Pawła z powrotu Tytusa z misji w Koryncie (2 Kor 7,5-6.13-16), w: M. P a n e k, J. W i 1 k (red.), Gratias agamus Domino Deo nostro. Księga Honorowa dedykowana Księdzu Jerzemu Palińskiemu Rektorowi Wyższego Ślaskiego Seminarium Duchownego w Katowicach w latach 2006-2013, Studia i Materiały Wydziału Teologicznego Uniwersytetu Śląskiego w Katowicach 77 (SiMWTUŚ), Katowice 2014, s. 298-310.

35 Zob. t e n ż e, Charakterystyka i zadania przełożonego wspólnoty chrześcijańskiej wedtug Listów Pasterskich. Studium biblijno-pragmatyczne, SiMWTUŚ 81, Katowice 2015.

36 Dalmacja (Dalmatia) - kraina leżąca wzdłuż wschodniego wybrzeża Morza Adriatyckiego, stanowiąca część Illirii, z głównym miastem Delminium. Od 27 r. po Chr. Dalmacja stała się rzymską prowincją; zob. Dalmacja, w: Z. P i s z c z e k (red.), Mała encyklopedia kultury antycznej, Warszawa 1983², s. 174.

37 W tym czasie Kościołowi na Krecie mógł przewodzić posłany tam przez Pawła Artemas (Tt 3,12).

38 Por. K. R o m a n i u k, Uczniowie i wspótpracownicy świętego Pawła, s. 179; Dzieje Pawła, Epizod XIV, 1.5.7, tłum. K. B a rd s k i, w: M. S t a r ow i e y s k i (oprac.), Apokryfy Nowego Testamentu, t. II, cz. 1, s. 456-460.

39 Por. Legenda Kreteńska Świętego Tytusa (Dzieje Tytusa), 12. 


\section{Łukasz}

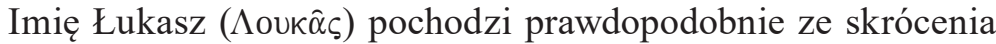
greckiego imienia $\Lambda$ ouк $\alpha \nu$ ó i funkcjonuje jako spieszczenie (forma hipokorystyczna). Znaczeniowo odpowiada imionom łacińskim $\mathrm{Lu}$ canus (,światło” lub ,pochodzący z Lukanii”), Lucius (,urodzony o świcie”, ,świetlisty"). ${ }^{40}$

W księgach Nowego Testamentu Łukasz został wymieniony tylko trzykrotnie i to wyłącznie w Corpus Paulinum (Kol 4,14; 2Tm 4,11; Flm 24). Mimo osobistego zaangażowania w drugą i trzecią podróż misyjną Apostoła Narodów, ${ }^{41}$ nigdzie nie wyeksponował swojej osoby. Pozostawił po sobie dzieło literackie (trzecia Ewangelia i Dzieje Apostolskie), ${ }^{42}$ ale nie autobiograficzne. Tak więc to, co wiemy o jego życiu, nie pochodzi bezpośrednio od niego. Według świadectw wczesnopatrystycznych (z II i III w.), wywodził się z Antiochii Syryjskiej. Z zawodu był lekarzem (Kol 4,14), a z potrzeby serca i wiary uczniem i wytrwałym towarzyszem Pawła. ${ }^{43}$ Nie znamy korzeni

40 Zob. Łukasz, w: H. Fro s, F. S ow a (oprac.), Księga imion i świętych, Kraków 1998, t. III, kol. 675; Łukasz, w: P.C. B o s a k, Postacie Biblii. Słownikkonkordancja, t. VII, s. 101.

${ }_{41}$ Świadczą o tym teksty Dziejów Apostolskich, w których Łukasz prowadzi narrację, stosując pierwszą osobę liczby mnogiej: „my”; zob. Dz 16,10-17; 20,5 21,$18 ; 27,1-28,16$.

42 Dzisiaj coraz rzadziej neguje się Łukaszowe autorstwo obydwu tych ksiąg.

43 Współczesna biblistyka dysponuje mnóstwem prac dotyczących Łukasza i jego dzieła. W kwestiach biograficznych zob. np. prace polskich uczonych: F. M i c k i e w i c z, Ewangelia wedtug świętego Lukasza (rozdziały 1-11). Wstęp, przekt. z oryginału, komentarz, Nowy Komentarz Biblijny. Nowy Testament III/1 (NKB. NT), Częstochowa 2011, cz. 1, s. 57-67; M. K i e d z i k, Łukasz-towarzysz i uczeń Pawła, w: W. C h r o s tow s k i (red.), Przybliżyło się królestwo Boże $(M k 1,15)$. Księga Pamiątkowa dla Księdza Profesora Romana Bartnickiego w 65. rocznice urodzin, Ad Multos Annos 12, Warszawa 2008, s. 229-239; H. L a n g k a m m e r, Ewangelia wedtug św. Łukasza. Przekt., wstęp i komentarz, Biblia Lubelska, Lublin 2005, s. 15-19; S. W ł o d a r c z y k, Święty Łukasz. Teolog historii zbawienia, Częstochowa 1995; F. G r y g l e w i c z, Ewangelia wedtug świętego Łukasza. Wstęp, przekt. z oryginału, komentarz, PŚNT III/3, Poznań-Warszawa 1974, s. 40-46; 
ich przyjaźni, ${ }^{44}$ ale apostoł w 2Tm 4,11 zaświadczył o sile ich więzi,

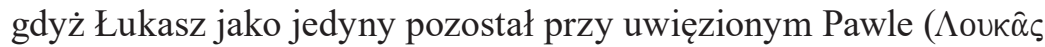

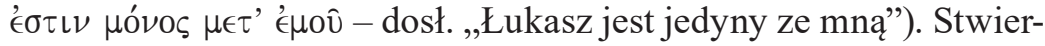

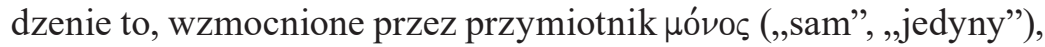
wydaje się sprzeczne z końcowym wersem, w którym Paweł śle Tymoteuszowi pozdrowienia od Eubulosa, Pudensa, Linusa, Klaudii i pozostałych braci (w. 21). Prawdopodobnie wymienione osoby to rzymscy chrześcijanie, dobrze znani Tymoteuszowi. ${ }^{45}$ Przez informację „tylko Łukasz jest ze mną”, apostoł mógł odnieść się do ludzi, którzy byli jego najbliższymi współpracownikami w dziele misyjnym, a obecnie dobrowolnie go opuścili (jak Demas) lub też zostali przez niego wysłani do dalszej pracy misyjnej (jak Krescens, Tytus czy inni nie wymienieni w tym passusie). Tak interpretując ten tekst, pełniej rozumiemy poczucie osamotnienia Apostoła Narodów. ${ }^{46}$ Dla niektórych badaczy Corpus Pastorale nota o trwaniu Łukasza przy uwięzionym apostole umożliwiła podjęcie dyskusji o jego ewentualnej roli w powstaniu Listów Pasterskich. ${ }^{47}$

Łukasz (wraz z Tytusem) miał pozostać przy Pawle aż do jego męczeńskiej śmierci. ${ }^{48}$ Co do jego dalszych losów nie mamy jednoznacznych informacji. Według Ojców Kościoła, po śmierci Apostoła Narodów miał on prowadzić aktywną działalność misjonarską w Dal-

E. D ą b row s k i, Dzieje Apostolskie. Wstęp, przekt. z oryginatu, komentarz, PŚNT V, Poznań 1961, s. 36-68.

${ }^{44}$ Być może sięgają one początku lat 50. i spotkania w Troadzie (zob. Dz 16,10-11).

45 Por. G.D. Fe e, Comentario de las Epistolas a $1^{a}$ y $2^{a}$ de Timoteo y Tito, s. 332 .

${ }^{46}$ Zob. pracę dotyczącą wrażliwej osobowości Pawła: G. C i r i g n a n o, F. M o n t u $\mathrm{s} \mathrm{h}$ i, La personalità di Paolo. Un approccio psicologico alle lettere paoline, Studi biblici 27, Bologna $1999^{2}$.

47 Zob. np. S.G. W i 1 s o n, Luke and the Pastoral Epistles, London 1979; J.D. $\mathrm{Q} \mathrm{u}$ i $\mathrm{n}$, The last volume of Luke. The Relation of Luce-Acts to the Pastoral Epistles, w: C.H. Ta 1 b e r $\mathrm{t}$ (red.), Perspectives on Luce-Acts, Edinburgh 1978, s. 62-75; N. B r o x, Lukas als Verfasser der Pastoralbriefe? Jahrbuch für Antike und Christentum 13/1970, s. 62-77; A. S t r o b e 1, Schreiben des Lukas? Zum sprachlichen Problem der Pastoralbriefe, New Testament Studies 15/1969, s. 191-210.

${ }^{48}$ Por. Dzieje Pawła, Epizod XIV, 1.5.7. 
macji, Galii, Italii, Macedonii i Achai. Nie brak jednak głosów, że z Rzymu udał się najpierw do Libii, a potem do Egiptu (Aleksandria i Teby). Istnieje również rozbieżność co do wieku, jakiego dożył Łukasz (70-85 lat) oraz miejsca i rodzaju jego śmierci (naturalnej lub męczeńskiej). ${ }^{49}$

\section{Marek}

Imię Marek (Môpкos, łac. Marcus) wywodzi się od Marsa - staroitalskiego bóstwa wiosny i rolnictwa, a u Rzymian boga wojny. Może ono oznaczać „mężczyznę”, „młot” lub „lśniący”. ${ }^{50}$

$\mathrm{Na}$ kartach Pisma Świętego imię to występuje ośmiokrotnie. Zachowało się ono zarówno w złożeniach (,Jan, zwany Markiem”Dz 12,12.25; 15,37), jak i samodzielnie (,Marek”- Dz 15,39; Kol 4,10; $2 \mathrm{Tm}$ 4,11; Flm 24; 1P 5,13). Nie jest całkowicie pewne, czy we wszystkich tych miejscach chodzi o tę samą osobę. Być może imię Jan wiązałoby się ze środowiskiem żydowskim (sam „Jan” - Dz 13,5.13), a Marek z rzymskim. Z czasem imię Marek stałoby się określeniem podstawowym. ${ }^{51}$

Prawdopodobnie Marek był synem Marii, w której domu gromadziła się pierwsza wspólnota chrześcijańska w Jerozolimie (zob.

49 Zob. K. R o m a n i u k, Uczniowie $i$ współpracownicy świętego Pawła, s. 102-104; K. M i e 1 c a r e k, Lukasz Ewangelista, w: Encyklopedia Katolicka (EncKat), t. XI, Lublin 2006, kol. 610-611; Męczeństwo świętego Lukasza Ewangelisty, tłum. W. W it a k o w s k i, w: M. S t a r o w i e y s k i (oprac.), Apokryfy Nowego Testamentu, t. II, cz. 2, s. 1104-1109.

50 Zob. Marek, w: P.C. B o s a k, Postacie Biblii. Słownik-konkordancja, t. VII, s. 223; Mars, w: Z. P i s z c z e k (red.), Mała encyklopedia kultury antycznej, s. 460.

51 Hebrajko-rzymska dwuimienność znana jest w pismach NT: „Szaweł zwany Pawłem” (Dz 13,9), , Józef zwany Barsabą z przydomkiem Justus” (Dz 1,23), „Szymon zwany Niger” (Dz 13,1), „Jezus zwany Justus” (Kol 4,11). Podwójne imiona nie świadczyły jednak o rzymskim obywatelstwie noszących je osób; zob. także R. F a b r i s, Paolo. L'apostolo delle genti, Donne e uomini nella storia 6, Milano 20085, s. 31-32. 
Dz 12,12) ${ }^{52}$ Bardzo wcześnie zetknął się z Piotrem, który, po uwolnieniu $\mathrm{z}$ więzienia, w jego rodzinnym domu spotkał (spotykał) modlących się chrześcijan (zob. Dz 12,12). Dla Piotra był jak syn (zob. 1P 5,13). ${ }^{53}$ Marek był bliskim krewnym Barnaby (zob. Kol 4,10), z którym towarzyszył Pawłowi podczas jego pierwszej podróży misyjnej (zob. Dz 13,5). Opuścił jednak zespół misyjny podczas trwania wyprawy i powrócił do Jerozolimy (zob. Dz 13,13). Z tego powodu Apostoł Narodów nie zgodził się, aby zabrać go w drugą podróż misyjną (zob. Dz 15,37-38). Na skutek powstałego sporu, Marek wraz z Barnabą wyruszył na Cypr (zob. Dz 15,39), a Paweł, zebrawszy nowy zespół misyjny (tworzyli go Sylas i Tymoteusz), przemierzał Azję Mniejszą i głosił Dobrą Nowinę w Europie (zob. Dz 15,40 - 18,18). List do Kolosan 4,10 oraz List do Filemona 24 wskazują, że Marek powrócił jednak do grona najbliższych współpracowników Pawła. ${ }^{54}$

W analizowanym passusie Apostoł Narodów polecił Tymoteuszowi, by ten, wyruszając w podróż do Rzymu, zabrał ze sobą Marka (2Tm 4,11). Trudno jednoznacznie określić, czy Tymoteusz miał zabrać Marka z Efezu, czy też z innego miejsca, w którym - za wiedzą Pawła - Marek przebywał.

Na uwagę zasługuje wyjaśnienie tej prośby: ,gdyż jest mi bardzo

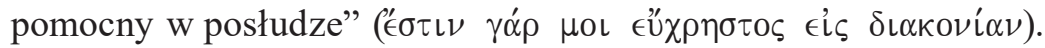
L. Oberlinner ${ }^{55} \mathrm{~W}$ powyższej wypowiedzi wyeksponował przymiotnik

52 Istnieje hipoteza, że w domu tym znajdowała się sala, w której Jezus wraz ze swoimi uczniami spożył Ostatnią Wieczerzę (zob. Mk 14,13-17). Marek mógłby wtedy być ,człowiekiem niosącym dzban wody” (Mk 14,13-15) i młodzieńcem nago uciekającym z ogrodu Getsemani (zob. Mk 14,51-52); zob. H. L a n g k a m m e r, Ewangelia wedtug św. Marka. Wstęp, przekt. z oryginału, komentarz, PŚNT III/2, Poznań-Warszawa 1977, s. 316.

53 Piotr mógł go ochrzcić. Marek był także jego współpracownikiem i tłumaczem w Rzymie; zob. E u z e bi u s z z Cezarei, Historia kościelna, III, 39, 15.

54 Więcej informacji o Marku zob. np. A. Ma 1 i n a, Ewangelia wedtug św. Marka $(1,1-8,26)$. Wstęp, przekt. z oryginału, komentarz, NKB.NT II/1, Częstochowa 2013, cz. 1, s. 52-57; A. P a c i o r e k, Marek Ewangelista, w: EncKat, t. XI, kol. 1269; H. L a n g k a m m e r, Ewangelia wedtug św. Marka, s. 27-33.

55 Por. t e n ż e, Zweiter Timotheusbrief, w: t e n ż e, Der erste Timotheusbrief. Der zweite Timotheusbrief, Herders theologischer Kommentar zum Neuen 
eu;crhstoj (,użyteczny”, ,przydatny”, „dogodny dla kogoś”). ${ }^{56}$ Wskazał, że w Nowym Testamencie termin ten występuje trzykrotnie (2Tm 2,21; 4,11; Flm 11), z czego w dwóch przypadkach (2Tm 2,21; Flm 11) odnosi się do ludzi, którzy zmienili się na lepsze. Analogicznie pro-

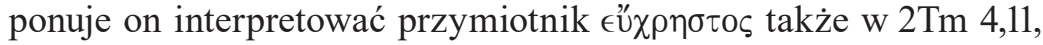
jako rehabilitację Marka, po opuszczenie przez niego w Pamfilii zespołu misyjnego (zob. Dz 13,13).

Inną kwestią jest próba wyjaśnienia, w czym Marek był tak bardzo przydatny uwięzionemu Pawłowi. Zastosowany w tekście rzeczownik

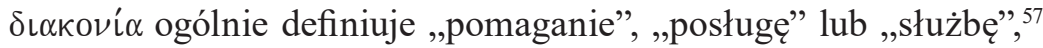
dlatego też może on oznaczać szeroko rozumianą posługę misyjną (podobnie jak np. w: Dz 1,17.25; 2Kor 4,1; 1Tm 1,12; 2Tm 4,5) lub osobistą pomoc uwięzionemu apostołowi (podobnie jak w 1Kor 16,15,

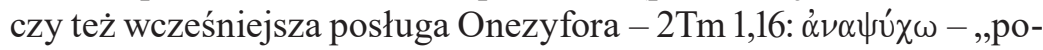
krzepiać”). Oba aspekty są do przyjęcia, jednakże ze względu na stałą obecność przy Pawle lekarza Łukasza, bardziej prawdopodobna wydaje się ewangelizacyjna posługa Marka. ${ }^{58}$

Testament - Ungekürzte Sonderausgabe, Freiburg im Breisgau-Basel-Wien 2002, s. $170-171$.

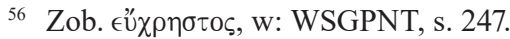

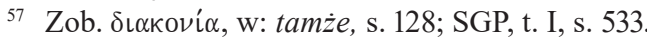

58 Por. J. S tę p i eń, Listy do Tesaloniczan i Pasterskie, s. 448; J a n C h r y z o s t o m, Homilia X na II List do Tymoteusza, X, 1: „Nie mówi, że ku jego wygodzie, lecz «ku posłudze» Ewangelii, gdyż i w więzieniu nie przestał obwieszczać Ewangelii. A więc i Tymoteusza wzywał w tym celu, nie dla siebie, lecz dla obwieszczania Ewangelii, aby przy jego śmierci nie powstało wśród wiernych żadne zamieszanie, gdy będą obecni liczni uczniowie, powstrzymujący rozruchy i pocieszający tych, którzy by nie mogli znieść spokojnie jego śmierci”. M. P r i o r uważa, że Paweł, gromadząc przy sobie te osoby, przygotowywał kolejny zespół misyjny. Uczony ten opowiada się za powstaniem $2 \mathrm{Tm}$ w czasie tzw. pierwszego uwięzienia Pawła w Rzymie. Według niego, apostoł oczekiwał wówczas na zbliżające się uwolnienie i dlatego też zaczął urzeczywistniać kolejne plany misyjne; zob. t e n ż e, Paul the Letter-Writer and the Second Letter to Timothy, s. 91-112, 146-149. 
Przypuszcza się, że Marek mógł być świadkiem śmierci zarówno Piotra, jak i Pawła. Według tradycji, sam miał ponieść śmierć męczeńską kilka lat później (ok. 68 r.). ${ }^{59}$

\section{Tychik}

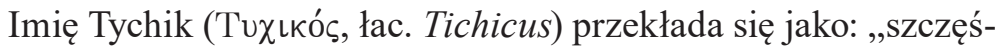
ciarz”, „pozostający pod opieką bogini szczęścia Tyche”, „dziecko szczęścia”, „szczęśliwy”. ${ }^{60}$ W Nowym Testamencie imię to znalazło się pięciokrotnie (Dz 20,4; Ef 6,21; Kol 4,7; 2 Tm 4,12; Tt 3,12), prawdopodobnie charakteryzując tego samego człowieka - towarzysza ostatniej podróży Pawła do Jerozolimy (zob. Dz 20,4) i jednocześnie wielokrotnie chwalonego przez niego współpracownika w dziele misyjnym (pozostałe teksty). Można przypuszczać, że podobnie jak Trofim pochodził on z Efezu (zob. Dz 20,4; 21,29), gdzie pierwszy raz mógł spotkać Apostoła Narodów. Był doręczycielem listów do Efezjan (zob. Ef 6,21-22) i Kolosan (Kol 4,7-9), jednakże został tam wysłany nie jako zwyczajny posłaniec, ale jako jeden z najbliższych towarzyszy Pawła, mający „pokrzepić serca” adresatów. Po spełnieniu tej misji był brany pod uwagę przez Apostoła Narodów jako ewentualny zastępca Tytusa na Krecie, którego Paweł wzywał do Nikopolis (zob. Tt 3,12).

Podczas drugiego uwięzienia Pawła w Rzymie, Tytus ponownie był przy nim. Wzywając Tymoteusza do siebie, który w tym czasie odpowiadał za Kościół w Efezie, wysłał na jego miejsca Tychika (zob.

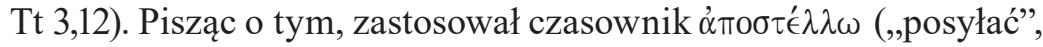
„Wysyłać”) w aoryście ( $\alpha \pi \epsilon \in \sigma \tau \epsilon \iota \lambda \alpha)$. Można go interpretować jako „,aoryst epistolarny”, który z perspektywy piszącego oznaczałby

59 Por. K. R o m a n i u k, Uczniowie i wspótpracownicy świętego Pawła, s. 115-116; Męczeństwo Świętego Apostoła i Ewangelisty Marka w Aleksandrii (Męczeństwo św. Marka), tłum. i oprac. M. S t a r ow i e y s k i, w: t e n ż e, Apokryfy Nowego Testamentu, t. II, cz. 2, s. 1095-1100.

${ }^{60}$ Zob. Tychik, w: P.C. B o s a k, Postacie Biblii. Słownik-konkordancja, t. IX, s. 702 . 
„wysyłam”, a z perspektywy adresata „właśnie wysłałem”. Wskazywałby on, że Tychik, który przypuszczalnie miał czasowo zastąpić Tymoteusza w Efezie, byłby również doręczycielem tegoż listu. ${ }^{61}$

Co działo się z Tychikiem po efeskiej misji, nie wiemy. Według przekazów pozabiblijnych miał zostać biskupem Chalcedonu w Bitynii. ${ }^{62}$ Inne teksty wskazują na biskupstwo w położonym niedaleko Efezu mieście Kolofon, ${ }^{63}$ a później na Neapolis na Cyprze, jako jego stolicę biskupią. ${ }^{64}$

\section{Karp}

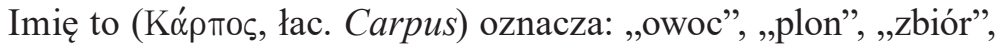
„nadgarstek". ${ }^{65}$ Chociaż znane jest w kulturze grecko-łacińskiej, ${ }^{66}$ w Nowym Testamencie występuje tylko raz (2Tm 4,13; hapax legomenon całej Biblii), określając chrześcijanina z Troady, znajomego Pawła. O obecności Apostoła Narodów w tym portowym mieście czytamy w Dz 16,8-11 (druga wyprawa misyjna); Dz 20,5-13; 2Kor 2,12 (trzecia podróż misyjna). Można założyć, że w jego domu zatrzymał

${ }_{61}$ G.D. F e e, Comentario de las Epístolas a $1^{a}$ y $2^{a}$ de Timoteo y Tito s. 333. Pogląd ten podważa I.H. Marshall, sugerując, że czasownik $\alpha \operatorname{m} \epsilon ́ \sigma \epsilon \epsilon \lambda \alpha$ nie jest „,aorystem epistolarnym”, a Tychik nie był doręczycielem listu. Tymoteusz w tym czasie miałby przebywać czasie poza Efezem (zob. 1Tm 1,3). Dzięki tej wiadomości miał dowiedzieć się, że Tychik został wysłany do Efezu. Można również przyjąć hipotezę, że Tymoteusz był w tym czasie w Efezie, ale Tychik miałby przybyć do tego miasta później niż posłaniec z listem; zob. I.H. M a r s h a 11, The Pastoral Epistles, s. 818; Te o d o r e t z Cyru, Komentarz do listów Pawłowych do Tesaloniczan, Tymoteusza, Tytusa, Filemona i Hebrajczyków, s. 179.

62 Zob. M. S t a r o w i e y s k i (oprac.), Imiona Apostołów. O siedemdziesięciu Apostolach, 57.

63 Zob. te n ż e (oprac.), Miejsca biskupstwa Siedemdziesięciu, w: t e n ż e, Apokryfy Nowego Testamentu, t. II, cz. 2, s. 1204.

64 Zob. tamże, s. 1205.

65 Zob. Karp, w: P.C. B o s a k, Postacie Biblii. Słownik-konkordancja, t. VI, s. 548.

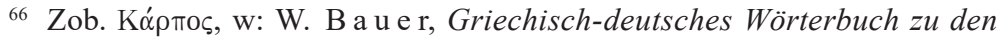
Schriften des Neuen Testaments und der frühchristlichen Literatur, kol. 821. 
(lub zatrzymywał) się Paweł podczas swoich krótkich pobytów w tym mieście.

Karp został wymieniony w kontekście podróży Tymoteusza do uwięzionego Pawła. Apostoł mógł przypuszczać, że Tymoteusz obierze trasę: Efez - Troada - Via Egnatia - Rzym. Prosił go, aby po drodze zabrał ,„płaszcz, który pozostawił u Karpa w Troadzie, oraz księgi, a zwłaszcza pergaminy". Istnieje hipoteza, że Paweł został aresztowany podczas powrotu do Efezu, albo przebywając w Milecie (zob. 2Tm 4,20) lub będąc w Troadzie, gdzie pozostawił (lub musiał pozostawić) kilka swoich rzeczy. ${ }^{67} \mathrm{Na}$ pierwszym miejscu wymienił $\phi \alpha \iota \lambda o ́ \nu \eta \varsigma$ (hapax legomenon całej Biblii): „gruba wierzchnia szata”, „płaszcz”. ${ }^{68}$ Jest to ciężkie, szorstkie w dotyku i pozbawione rękawów okrycie, utkane najczęściej z sierści wielbłądziej lub koziej, z otworem na środku umożliwiającym przełożenie przez głowę (podobne do poncho?) bądź zapinane na guziki, okrywające całe ciało. Często stosowane w zimie lub podczas deszczu (łac. paenula). ${ }^{69}$

Oprócz płaszcza, apostoł prosił Tymoteusza o przywiezienie

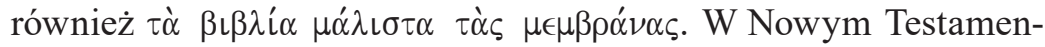

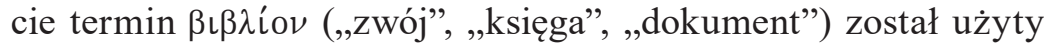
jako określenie zwojów (np. Ap 6,14); pism Starego Testamentu (Łk 4,17.20; Ga 3,10; Hbr 9,19; 10,7); pism Nowego Testamentu (J 20,30; 21,25; Ap 1,11;22,7.9.10.18.19); ksiąg mistycznych, księgi życia (np. Ap 5,1.2.3.4.5.8.9) oraz dokumentów rozwodowych (Mt 19,7;

67 Por. G.D. Fee, Comentario de las Epístolas a $1^{a}$ y $2^{a}$ de Timoteo y Tito, s. 333.

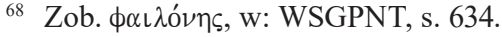

${ }^{69}$ Por. B. S z c ze pa now icz, B. We s ołows k a - Kow a 1 s ka, Moda w Biblii. Odziė, obuwie, nakrycia głowy, fryzury oraz kosmetyki i ozdoby, Kraków 2011, s. 99; C. M a r c h e s e 11 i- C a s a l e, Le Lettere Pastorali. Le due lettere a Timoteo e la lettera a Tito. Introduzione, versione, commento, Scritti delle origini cristiane 15, Bologna 2008², s. 805-806; W. L o c k, A Critical and Exegetical Commentary on the Pastoral Epistles, s. 118; P. B i 11 e r b e c k, Die Briefe des Neuen Testaments und die Offenbarung Johannis erläutert aus Talmud und Midrasch, Kommentar zum Neuen Testament aus Talmud und Midrasch 3, München 1954², t. III, s. 666. 
Mk 10,4) ${ }^{70}$. Natomiast leksem $\mu \epsilon \mu \beta \rho \alpha ́ \nu \alpha$ (,skóra”, „błona”, „pergamin") znalazł zastosowanie tylko w omawianym tekście (hapax legomenon całej Biblii) ${ }^{71}$. Brak jest jednomyślności co do odpowiedzi na pytanie, dlaczego apostoł rozróżnił $\beta \iota \beta \lambda$ íov i $\mu \in \mu \beta \rho \alpha ́ \nu \alpha$. Wysuwa się zarówno argumenty dotyczące kwestii technicznych (papirus pergamin; kodeks - zwój), jak i zapisanych na nich treści (księgi Starego Testamentu; zbiór listów Pawła; jego osobisty „notatnik”; dokumenty personalne, pisma powstające w rozwijającym Kościele zob. Łk 1,1). „Księgi” mogą też oznaczać dokumenty już zredagowane, a ,pergaminy” materiał piśmienniczy jeszcze niewykorzystany, umożliwiający powstanie nowych tekstów ${ }^{72}$.

W opracowaniach dotyczących przekazu zawartego w 2Tm 4,13 wskazuje się także na parenetyczno-teologiczne znaczenie zadania, które otrzymał Tymoteusz. Trudno bowiem zakładać, że drugie uwięzienie Pawła oraz sytuacja chrześcijan w Rzymie po pożarze miasta w lipcu 64 r. spowodowała, że apostoł byłby pozbawiony tego wszystkiego, o czym wspomniał w 1Tm 6,8. Tym bardziej że nie pozostawał sam (zob. 2Tm 1,16-18; 4,21).

P. Trummer ${ }^{73} \mathrm{~W}$ prośbie tej dostrzega intencję redakcyjną autora pisma, który przez przykład Apostoła Narodów chciał wzmocnić w odpowiedzialnych za poszczególne wspólnoty chrześcijańskie

70 Zob. $\beta \iota \beta \lambda$ iov, w: WSGPNT, s. 96.

71 Zob. $\mu \epsilon \mu \beta \rho \alpha ́ \nu \alpha, \mathrm{w}:$ tamże, s. 384.

72 Por. często rozbieżne opinie np. C. M a r c h e s e 11 i - C a s a le, Le Lettere Pastorali, s. 806-808; P.H. Tow n e r, The Letters to Timothy and Titus, The New International Commentary on the New Testament, Grand Rapids-Michigan-Cambridge 2006, s. 629-630; A. W e i s e r, Der zweite Brief an Timotheus, Evangelisch-Katholischer Kommentar zum Neuen Testament XVI/1, Zürich-Neukirchen-Vluyn

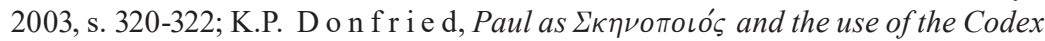
in Early Christianity, w: K. K e r te 1 g e, T. H o $1 \mathrm{t}$ z, C.P. M ä r z (red.), Christus bezeugen. Festschrift für Wolfgang Trilling zum 65. Geburtstag, Erfurter Theologische Studien 59, Leipzig 1989, s. 249-256; J. S t ę p i e ń, Listy do Tesaloniczan i Pasterskie, s. 448.

73 Por. t e n ż e, „Mantel und Schriften“ (2Tim 4,13). Zur Interpretation einer persönlichen Notiz in den Pastoralbriefen, Biblische Zeitschrift 18 (1974) z. 2, s. 207. 
skromność i wstrzemięźliwość (symbol płaszcza) oraz miłość do Pisma Świętego (symbol ksiąg i pergaminów).

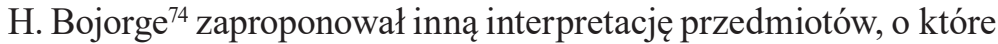
prosił uwięziony Paweł: „Co [przez nie] mógł chcieć powiedzieć Paweł? W świetle tego pytania, nie może w mniejszym stopniu zwrócić naszej uwagi koegzystencja w tym samym wersie dwóch przedmiotów, które stanowią powód do zasugerowania dwóch centralnych miejsc teologicznych dla kontekstu całego listu: 1. płaszcz (Tradycja), 2. księgi i pergaminy (Pisma)". Tym samym Apostoł Narodów w prośbie skierowanej do Tymoteusza (w. 13), odniósłby się do sukcesji apostolskiej, którą przekazał swojemu ,umiłowanemu dziecku w wierze" (1Tm 1,2; 2Tm 1,2) i jednocześnie zwierzchnikowi Kościoła w Efezie. ${ }^{75}$

Powróćmy jeszcze do osoby Karpa. O jego dalszych losach trudno coś dokładniej powiedzieć. Według tradycji apokryficznej, miał zostać biskupem w Berei w Tracji. Tam też jest przedstawiany jako męczennik. ${ }^{76}$

\section{Aleksander}

Powszechnie znane w kulturze antycznej imię Aleksander ${ }^{77}$ ('A $\left.\lambda{ }^{\prime} \xi \xi \alpha \delta \rho o \varsigma\right)$ oznacza: „,broniący mężów”, „troszczący się o mężów”, ,pomocnik ludzi”, „obrońca”. ${ }^{78}$ W Nowym Testamencie imię

74 Te n ż e, El poncho de san Pablo. Una posibile alusión a la sucesión apostolica en 2 Timoteo 4,13, Revista Bíblica 178 (1980) z. 4, s. 224.

75 Por. tamże; przeciwko tej opinii: A. W e is e r, Der zweite Brief an Timotheus, s. 319 .

76 Zob. Karp, w: H. Fro s, F. S o w a (oprac.), Księga imion i świętych, t. III, kol. 439; M. S t a r ow i e y s k i (oprac.), Imiona Apostołów. O siedemdziesięciu Apostołach, s. 58; t e n ż e (oprac.), Miejsca biskupstwa Siedemdziesięciu, s. 1204.

77 Zob. Aleksander, w: Z. P is z c z e k (red.), Mała encyklopedia kultury antycznej, s. 30-31, gdzie pokrótce przedstawiono życiorysy wybitnych osób starożytności noszących to imię. Wśród nich znajduje się Aleksander Wielki Macedoński (356-323 przed Chr.).

78 Zob. Aleksander (brązownik), w: P.C. B o s a k, Postacie Biblii. Stownikkonkordancja, t. I, s. 265. 
to zostało wymienione sześciokrotnie, zasadniczo odnosząc się do różnych osób (Mk 15,21; Dz 4,6; 19,33a.b; 1Tm 1,20; 2Tm 4,14). Wątpliwość rodzi się w Corpus Pastorale, a dotyczy ona pytania, czy „ekskomunikowany” przez Apostoła Narodów Aleksander z 1Tm 1,20 jest tożsamy w Aleksandrem brązownikiem z $2 \mathrm{Tm} 4,14 .{ }^{79}$ Wielu uczonych twierdzi, że tak, ${ }^{80}$ ale nie mamy żadnych informacji zdecydowanie popierających lub negujących to założenie. ${ }^{81}$ Równie dobrze, mógł to być całkiem inny Aleksander, jakiś mieszkaniec Troady, o którym Paweł przypomniał sobie w kontekście prośby skierowanej do Tymoteusza, a dotyczącej pozostawionych w tym mieście ksiąg i pergaminów (w. 13). ${ }^{82}$

Aleksander w analizowanej perykopie został określony jako $\chi \alpha \lambda \kappa \in u ́ s$. Leksem ten ogólnie definiuje rzemieślnika obrabiającego metale (żelazne i nieżelazne). ${ }^{83} \mathrm{~W}$ Nowym Testamncie termin ten użyty został tylko raz (hapax legomenon). ${ }^{84}$ Człowiek o tym imieniu wyrządził Pawłowi wiele zła. Apostoł przestrzegał Tymoteusza (w. 15), aby ten na skutek działań Aleksandra nie musiał doświadczyć

79 Istnieją opinie poszerzające to pytanie również wobec ustalenia tożsamości Aleksandra z Dz 19,33-34. Aleksander wspomniany w Dz 19,33-34 oraz w 1Tm 1,20; 2Tm 4,14 byłby tą samą osobą; zob. np. A.E. M a r tí n e z, Timoteo y Tito, s. 102; G.W. K n i g h t III, The Pastoral Epistles. A Commentary on the Greek Text, The New International Greek Testament Commentary, Grand Rapids-Michigan 1999², s. 467.

80 Np. I.H. M a r s h a 11, The Pastoral Epistles, s. 821; N. B r o x, Die Pastoralbriefe. 1 Timotheus. 2 Timotheus. Titus, Regensburger Neues Testament Regensburg $1989^{5}$, s. 274.

81 Przeciw identyfikacji tych osób może sprzyjać fakt, że Aleksander wspomniany w 2Tm 4,14-15 nadal prowadził swoją destrukcyjną działalność (w w. 15 Paweł ostrzega przed nim Tymoteusza). Nie wiemy jednak dokładnie, na czym polegało i jakie konsekwencje pociągało za sobą owo „przekazanie szatanowi” Aleksandra wymienionego wraz z Hymenajosem w 1Tm 1,20.

82 Por. G.D. F e e, Comentario de las Epístolas a $1^{a}$ y $2^{a}$ de Timoteo y Tito, s. 334.

83 X $\alpha \lambda \kappa \in \cup ́ \varsigma$, w: WSGPNT, s. 650: „obrabiający miedź, brąz lub spiż”, „,brązownik”, „kotlarz”, ,płatnerz”, „obrabiający metal”, „,kowal”.

${ }^{84}$ LXX: Rdz 4,22; 2Krn 24,12; Ne 3,32; Hi 32,19; Syr 38,28; Iz 41,7; 54,16. 
tego samego cierpienia. Pozostaje wciąż kwestią otwartą, co Paweł

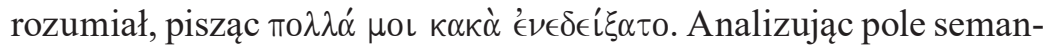

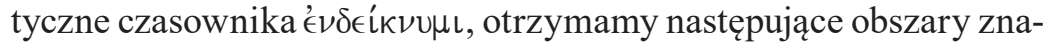
czeniowe: 1. „pokazać”, „wskazać”; 2. „donieść na kogoś”; „donieść komuś”; 3. „wyjawić o sobie coś”; 4. „okazać”, „wyrazić”; 5. „chcieć się przypodobać komuś". ${ }^{85}$ Obszar 2 oraz 5 tego pola sprzyja hipotezie, że Aleksander mógł się przyczynić do aresztowania Pawła. W kwestii tej brak jest jednak jednomyślności wśród uczonych zajmujących się Listami do Tymoteusza. Faktem jednak było, że stanowił on wciąż realne zagrożenie dla najbliższych towarzyszy Apostoła Narodów,

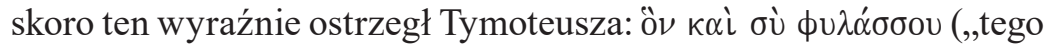
i ty strzeż się", „uważaj i ty na niego").

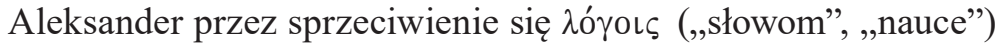
Pawła mógł również należeć do grupy jego oponentów (fałszywych nauczycieli; heretyków lub apostatów), podobnie jak Hymenajos i Filetos (2Tm 2,17-18; zob. także 2Tm 3,1-9).

Apostoł Narodów nie polecił Tymoteuszowi jakiegokolwiek negatywnego działania wobec Aleksandra, ocenę bowiem jego postępowania pozostawił Panu (w. 14; zob. Ps 28[27],4).

$$
* * *
$$

Ze względu na odniesienie (relację) do Apostoła Pawła, osoby imiennie wymienione w 2Tm 4,9-15 można podzielić na dwie grupy. Pierwszą tworzą ci, którzy wytrwali przy nim, byli do niego pozytywnie nastawieni, bądź w czasie jego uwięzienia spełniali wyznaczone przez niego misje. Są to: Krescens (?), Tytus, Łukasz, Marek, Tychik i Karp. Grupę drugą stanowią najbliżsi jego współpracownicy, który z bliżej nieznanych nam przyczyn opuścili Pawła lub stali się (albo od pierwszego spotkania już nimi byli) jego zagorzałymi przeciwnikami. Do tej grupy zaliczamy: Demasa i Aleksandra.

85 Zob. '̇ $\nu \delta \epsilon i ́ \kappa \nu \nu \mu \iota$, w: SGP, t. II, s. 130; WSGPNT, s. 198. W NT występuje 11 razy. 
Życie każdego z nich było w różnej mierze związane z życiem Pawła. Życie Pawła również zostało wzbogacone lub negatywnie dotknięte przez kontakt z tymi osobami. W tym kontekście apostoł jawi się jako człowiek szukający relacji z drugim człowiekiem i jednocześnie realnie oceniającym zachowania oraz postawy stykających się z nim ludźmi. W kontaktach był uważnym i wrażliwym człowiekiem, ale nie pozwalającym się skrzywdzić, zniechęcić trudnościami lub negatywnymi relacjami.

Jeśli przyjmiemy Drugi List do Tymoteusza za Pawłowy, to każda $\mathrm{z}$ tych osób, imiennie wyliczonych $\mathrm{w}$ analizowanym passusie, $\mathrm{w}$ jakiejś mierze zajmowała umysł uwięzionego apostoła. Jeśli opowiemy się za pseudonimią, otrzymany rejestr ludzi, którzy zdaniem pseudoepigrafa wyraźnie zaznaczyli się w ostatnim etapie życia Apostoła Narodów. Przypuszczalnie dla pierwotnego Kościoła wszelkie imienne odniesienia do konkretnych osób (często powszechnie znanych wspólnotom chrześcijańskim), mogły stanowić aluzje do aktualnych sytuacji w poszczególnych społecznościach wyznawców Chrystusa.

Osoby wymienione w $2 \mathrm{Tm}$ 4,9-15 uwydatniają ponadto prawdę, że sama obecność wybitnego świadka Chrystusa, jakim był Paweł, nie gwarantuje jeszcze stałej i głębokiej wiary stykających się z nim ludzi. Potrzebne jest także osobiste, pozytywne zaangażowanie oraz wytrwałość. Bez nich przyjmuje się postawę Demasa lub brązownika Aleksandra.

ks. Janusz WILK

Słowa kluczowe: Drugi List do Tymoteusza, Demas, Krescens, Tytus, Łukasz, Marek, Tychik, Karp, Aleksander

Keywords: The Second Letter to Timothy, Demas, Crescens, Titus, Luke, Mark, Tychicus, Carpus, Alexander 


\section{References to Persons in the Second Epistle to Timothy 4:9-15 Summary}

The article comprises theological deliberations on the persons referred to by name in 2 Timothy 4:9-15. These persons can be divided into two groups. The first group consists of those who remained with the Apostle Paul, had a positive attitude towards him, or completed missions appointed by Paul during his imprisonment. They are as follows: Crescens (?), Titus, Luke, Mark, Tychicus and Carpus. The second group comprises his closest collaborators who, for unknown reasons, abandoned Paul, or became (or had been from the first meeting) his fierce opponents. Demas and Alexander belong to this group.

If we assume that the Second Epistle to Timothy was written by Paul, each of those individuals referred to in the analysed passage occupied, to some extent, the mind of the imprisoned Apostle. If we assume that 2 Timothy is a pseudepigraph, we obtain a list of people who, according to the author of the text, had clear influence on the Apostle of the Nations during his final stage of life. In the times of the early Church, all name-based references to specific people (who were often well regarded] in Christian communities), might have constituted obscure references to current situations in the respective communities of the followers of Jesus Christ. 